\title{
Utility Manning: Young Filipino Men, Servitude and the Moral Economy of Becoming a Seafarer and Attaining Adulthood
}

Work, Employment and Society 2019, Vol. 33(4) 580-595 (C) The Author(s) 2018

Article reuse guidelines: sagepub.com/journals-permissions DOI: $10.1 \mid 77 / 0950017018760182$ journals.sagepub.com/home/wes

\section{Roderick G Galam}

Free University of Berlin, Germany

\begin{abstract}
To get a job as a seafarer in the global maritime industry, thousands of male Filipino youths work for free as 'utility men' for manning agencies that supply seafarers to ship operators around the world. Based on ethnographic fieldwork and approached from a moral economy perspective, this article examines how manning agencies and utility men differentially rationalize this exploitative work (utility manning). Manning agencies use it as a technology of servitude that, through physical and verbal abuse and other techniques, enforces docility to prepare utility men for the harsher conditions on-board a ship. In contrast, utility men use it as a technology of imagination, gleaning from it a capacity to shape their future. Faced with few social possibilities in the Philippines, they deploy servitude as a strategy for attaining economic mobility and male adulthood.
\end{abstract}

\section{Keywords}

adulthood, imagination, moral economy, seafaring, servitude, utility manning, waithood, youth unemployment

\section{Introduction: Youth unemployment, adulthood and masculinity}

Thousands of young Filipino men who have finished three or four years of maritime education and who want to work in international seafaring willingly go through servitude to obtain a placement with manning agencies that supply seafarers to ship operators around the world. Called 'utility men' (gofer or flunkey), they work for free in exchange

\section{Corresponding author:}

Roderick G Galam, Institute of Social and Cultural Anthropology, Free University of Berlin, Landoltweg

9-II, I4195 Berlin, Germany.

Email: galamrg@zedat.fu-berlin.de 
for a future job on a ship. During this time, they undertake clerical and janitorial tasks, as well as domestic work like cleaning, washing and ironing clothes, and looking after babies and small children for the agency owners and their families. Many others scout for seafarers their agencies urgently need, or liaise with embassies for the transit visa applications of seafarers hired by their manning agency. Some become personal drivers or work in the agency owner's farm or internet shop. Some work for a few months, others for two years or even longer. Utility men say they are used (ginagamit) and exploited (pinapakinabangan). They, however, endure despite the abuse and cruel mistreatment for the chance of becoming a seafarer, which is their means of attaining male adulthood and a significantly better life.

These are impossible to achieve if they stayed and worked in the Philippines, where employment offers no real prospects for upward social and economic mobility. In 2016, more than 26 million Filipinos out of 41.3 million workers (equivalent to almost 63\%) are non-regular, agency-hired, informal sector and/or unpaid family workers. This means low-paying and insecure work with poor or no benefits (IBON Foundation, 2016). Almost $50 \%$ of the 2.363 million unemployed Filipinos belong in the youth category (15-24 years old) (Philippine Statistics Authority, 2017). ${ }^{1}$ Although fewer male youths (45.3\%) are unemployed compared to females (52.8\%), between 2008 and 2012 more young men (almost 25\%) with secondary and tertiary education were unemployed compared with women at 21\% (Danish Trade Council for International Development and Cooperation (DTCIDC), 2016). The opportunity for social and economic mobility provided by international seafaring is a real inducement for prospective seafarers to undertake utility manning. Using International Transport Workers Federation (ITF) rates, the lowest-ranked seafarer, catering boy, earns more than US\$1100 (or 55,000 Philippine pesos) a month, almost nine times the average monthly income of 6400 pesos (US\$128) of a Filipino minimum wage worker (Department of Labor and Employment (DOLE), 2017). The average monthly income of a seafarer with a ratings position (meaning, nonofficer) is about US\$1575. Officer seafarers earn a lot more: a ship captain and chief engineer earn about US\$6000 and US\$5300 respectively (ITF, 2014).

This article examines the dynamic that underpins utility men's strategy of obtaining a job, which is linked to how young men transition towards male adulthood. It investigates how manning agencies use utility manning as a technology of servitude, on the one hand, and how utility men use it as a technology of the imagination, on the other hand. Through abusive and exploitative practices, manning agencies not only enforce docility but also attempt to produce compliant workers who will 'not cause trouble' on-board a ship. Here, 'technology' refers to 'modes of training and modification of individuals not only in the obvious sense of acquiring certain skills but also in the sense of acquiring certain attitudes' (Foucault, 1997: 225). As such, it encompasses the techniques and practices by which certain human dispositions and ways of relating are realized (Rose, 1999: 52). In contrast, utility men recast their servitude into the means by which they could secure their future and adult social status during a time when young people's life chances and social possibilities have become very limited.

The deindustrialization and rise of the service economy that advanced economies have gone through in the past few decades have led to changes in the labour market and the nature of employment, in the process altering employment opportunities for both 
men and women. While expanding the labour market for women, they also led to a feminization of labour - work came to require qualities and skills traditionally associated with women (Fernandez-Kelly, 2005; McDowell, 2003). These changes led to a 'crisis in masculinity' (Beynon, 2002). In the UK, the rise of service-sector employment and contingent work - reinforced by structures of class inequality and geographical variations in labour market changes and housing market opportunities - have made it more difficult for working-class male youths to attain the basic attributes of adulthood (McDowell, 2003). In many developing countries, economic restructuring associated with neoliberal reforms shrank government spending for public services, directly affecting the employment opportunities of young people at a time when secondary and university education participation rates were on the rise (Jeffrey, 2008; Mains, 2013; Sommers, 2012).

Young people in both developed and developing countries are facing 'austerity, diminishing public welfare and fragmentation of formal employment' (Thieme, 2017: 1), which together have severely depressed their employment opportunities and caused a failure or delay in their transition to adulthood (Honwana, 2012; Jeffrey, 2008; Mains, 2013; Sommers, 2012). Adulthood is often associated with financial and economic independence, having one's own house, being married, having children and being able to help families rather than being dependent on parents and relatives (Hansen, 2005; Masquelier, 2005). Young people are stuck in a protracted youthhood or waithood, the 'involuntary delay in reaching adulthood' (Honwana, 2012: 4).

Although young people in the Global South face more challenging circumstances as opportunities and resources for attaining male adulthood diminish, the prerequisites for becoming and the social expectations of what it means to be an adult have remained recalcitrant (Mains, 2013; Sommers, 2012). In Rwanda, male youths' failure to attain adulthood has serious consequences on female adulthood since the latter depends on the former. As Sommers (2012: 6) writes, because 'a female youth ... cannot be accepted as a woman until she marries and has children, she is dependent on whether and when male youth are able to become men'. In the Philippines, masculinity remains fundamentally defined by breadwinning (McKay, 2011; Parrenas, 2005; Pingol, 2001). While women could choose to become full-time mothers, and therefore, still perform a legitimate gender and social role, men who become a fully dependent spouse risk social ostracism. Consequently, young Filipino men, like other young men in the world (Mains, 2013; Sommers, 2012), face a stronger social pressure to find decent work to be able to perform the masculine role of providing for their (future) family.

Scholarly attention is increasingly being given to how young men in countries where economic crisis has become chronic improvise to negotiate their everyday lives and future. Studies show how they have deployed different forms of provisional agency, 'a temporary means of mobility geared towards a better future' (Jauregui, 2014: 76), as mechanisms to cope with and negotiate the uncertainties and the existential crisis of a protracted or indefinite waithood. Jeffrey (2010) writes about how male youths in Uttar Pradesh, India, delay job search by accumulating multiple postgraduate degrees. This enables their parents to say that they are near to obtaining a good job which improves their marriage prospects. These men engage in 'timepass', or the practice of masculine waiting by which young men 'mark their social suffering and begin to negotiate their unemployment' (Jeffrey, 2010: 102). In Freetown, Sierra Leone, male youth deploy 'straining' or 
'the need and struggle to make ends meet' both to earn a living to support their family and to attain adulthood (Finn and Oldfield, 2015: 32). Mains (2013) shows how young Ethiopian men undertake internal migration to work in internationally funded development projects, work that enables them to temporarily reposition themselves from being dependent on others to being depended upon by others, which is an important aspect of their assumption of adulthood. Thieme (2017: 3) highlights how the practice of 'getting by' of Nairobi youth living in ghettos through 'hustling' also shows their coping mechanism as they go through their 'everyday struggles, dealings and opportunistic practices in the absence of formal institutional support of any kind'. She underscores how youth engaged in informal waste labour derive and exercise agency 'through the deliberate appropriation ... of the seemingly least desirable forms of work' (Thieme, 2017: 13).

Utility manning is an informal and individually negotiated pathway towards work. As a strategy for transitioning from education to work, utility manning might be seen in relation to apprenticeships and internships. In the past, utility men were called 'OJTs', meaning that they were doing on-the-job training. In reality, however, the work they do has no relation to their education or to the job they will do as seafarers. Utility manning is not therefore a form of apprenticeship that combines school-based and firm-based training that are specifically designed to lead to occupation (Kohlrausch, 2012). They were called 'OJT' to mask their exploitation. In terms of its purpose, it shares elements with internships in that it is a way of 'getting a foot in the door' without necessarily providing work-related training and where interns are also exploited. However, whereas internships remain the preserve of those with the right social and financial capital (Roberts, 2017), utility manning is resorted to by those with the least social capital. Although utility manning is abusive and exploitative, it is not coercive. Utility men voluntarily apply for servitude and are free to leave at any time. They seek it out and endure it because they have no other options.

The ways of navigating an environment hostile to transitioning from youthhood to adulthood highlighted in the preceding discussion involve elements of pragmatism, opportunism and improvisation. While studies focus on informal work and livelihood activities which do not offer the possibility of progressing to 'formal employment' (Finn and Oldfield, 2015; Mains, 2013; Thieme, 2017), this article contributes to research on the strategies used by young men to navigate employment uncertainties and uncertain transitions to adulthood by examining how servitude leads to the world of 'formal', well-remunerated, albeit contractual, work. It also contributes to sociological research on international seafaring labour. Studies that have examined the exploitation of this group of workers have focused on those who have already worked or are working in the industry (Bloor, 2011, 2013; Chapman, 1992; Couper et al., 1999; McKay, 2007; Walters and Bailey, 2013). This article focuses on prospective ones willing to be exploited just to become a seafarer. Finally, it contributes to scholarship on work and masculinity by highlighting how the utility men deploy servitude, which entails subordination, emasculation and feminization, to achieve masculine adulthood. To reveal the dynamics that frame and undergird utility manning, this article approaches servitude from a moral economy perspective.

\section{The moral economy of utility manning}

From 2010 to 2013, almost 79,300 students enrolled each year to undertake a maritime degree in marine engineering or marine transportation (Commission on Higher Education, 
2016, personal communication) but only 3000 are absorbed each year by manning/crewing agencies. There are almost 500 manning and crewing agencies in Manila recruiting seafarers for the shipping industry that has progressively outsourced its workforce (Bloor and Sampson, 2009), a consequence of the deregulation in the 1970s of the global maritime industry (Alderton and Winchester, 2002). Young men seeking their first shipboard experience are disadvantaged by the preference of manning agencies for those who have sailed. Prospective seafarers make up for this disadvantage through utility manning. Due to the sheer number of applicant seafarers, many manning agencies adopted a policy of accepting only utility men related or known to a seafarer they employ or member of staff. They do this as a favour to seafarers who in turn are expected to show loyalty to them by not moving to other agencies despite the higher salaries offered.

The young men's reliance on exploitative relationships fills in the space created by the withdrawal or absence of the state (Rudnyckyj, 2004). As an oversupply of maritime education graduates creates fierce competition, in part a result of the failure of the state to properly regulate maritime education, informal ties and processes become the norm in the context of weak formal linkages between maritime schools and manning agencies. Although shipowners through their manning agencies now offer cadetships to maritime students, recipients represent only a small percentage of all prospective seafarers.

The exploitative manning agency-utility men relationship exhibits a dynamic characteristic of patron-client ties that can be elaborated on more conceptually and analytically from a moral economy perspective developed by James Scott (1972, 1976). Thompson (1971) first used 'moral economy' in the context of food riots in England in the 18th century. Thompson argued that people's actions to assert their access to bread were based on customary values and practices that entitled people to expect those in authority to protect them from profiteers. Scott (1976) extended the concept to examine patron-client relations in the peasant societies of South-East Asia. Two sets of literature on moral economy are most relevant to my topic here: labour brokering and contingent work. Rudnyckyj (2004) looks at labour brokers and migrant workers through this lens but notes the failure of labour brokers to come to the aid of the workers (and therefore do not function perfectly as patrons). 'Moral economy' has been used in studies of contingent work (Bolton et al., 2012; Bolton and Laaser, 2013) but which, because they draw on Thompson (1971), do not consider its operation within or alongside patron-client networks which underpins utility manning.

Scott's concept of 'moral economy' provides a 'phenomenological theory of exploitation' (Scott, 1976: 161) based on patron-client networks. Scott (1972: 98) defines a patron-client relationship as involving:

an individual of higher socio-economic status (patron) [who] uses his own influence and resources to provide protection and/or benefits for a person of lower status (client) who, for his part, reciprocates by offering general support and assistance, including personal services, to the patron.

The minimum demands of the peasant are physical security and a subsistence livelihood (Scott, 1972). The expectation of the provision of these demands is at the root of the peasants' moral economy, that is, 'their notion of economic justice and their working definition of exploitation - their view of which claims on their product were tolerable 
and which intolerable' (Scott, 1976: 3). Scott (1972) emphasizes the patron-client dyad's basis in inequality. Although the patron-client network is built on a relationship that is inherently unequal and exploitative, its morality derives from the expectation and fulfilment of obligations that each party has for the other.

Kerkvliet (2013), writing on patron-client relationships in a village in Central Luzon, Philippines, notes that patron-client ties, which earlier in the 20th century were most frequently to be seen in landlord-tenant relationships, now form primarily between lenders and borrowers, landholders and agricultural workers, and employers and employees (Kerkvliet, 2013: 221, emphasis added). The case of utility men seeking the patronage of manning agency owners and bosses indicates the extension of this type of network beyond agrarian relations. Their reliance on such ties reveals the absence of effective state presence in, and provision for, social welfare service. As noted by Rudnyckyj (2004: 414), social science research in South-East Asia and other parts of the world has shown that the absence of strong state institutions engenders the significance of patronclient ties in these societies.

Young Filipino men actively and willingly seeking out their servitude and exploitation demonstrate both the structural constraints they face and the form of tactical agency they are able to exercise within these constraints. Although there are thousands of utility men, individually or collectively they cannot engage in activities that would undermine their manning agencies or challenge the authority of their bosses. They cannot footdrag or employ others forms of 'weapons of the weak' while doing their work or dealing with bosses or agency staff. To do so would be to undermine themselves as well as whoever helped them gain entry into the agency.

\section{Methods}

This article draws on an ongoing qualitative study of youth unemployment in the Philippines that used participant observation, life history interviews and semi-structured interviews. The data reported here come from 10 months of fieldwork conducted between 2014 and 2015 in Manila, Philippines.

\section{Life history interviews}

Life history interviews, each lasting at least one hour, were conducted with 65 utility men. They were selected through purposive sampling on the basis of age range (19-24 and 25-above) and length of time working as utility men to obtain a variety of perspectives on waiting, unemployment and servitude. The interviews inquired about the utility men's family background and life, their experiences of looking for a position as a utility man and of working as one and the hopes and aspirations they have pinned on it. Life history interviews enable the attainment of a high degree of historical depth and allow for 'deep description, texture and detail' (Lewis, 2008: 561). Because they are concerned with the temporal dimension of individuals and their actions, they locate utility men's life and work through time. Consequently, they locate the utility men within wider social contexts and relations (Elliott, 2005: 4) and their trajectory through time and space. 


\section{Semi-structured interviews}

Semi-structured interviews were conducted with five seafarers who have sailed for a number of years and who worked as utility men when they were starting out, to find out whether this servitude as a strategy of obtaining work paid off. Four individuals who benefitted from the work of utility men were also interviewed this way to obtain perspectives on the practice of having utility men provide unpaid work and their treatment: two seafarer union officials; a crewing manager in charge of seafarer recruitment and deployment; and a fleet manager of one of Manila's biggest manning agencies. Semi-structured interviews were done with this group of participants because topics covered had been identified beforehand based on the interviews with utility men.

\section{Participant observation}

Six months of participant observation at Manila's informal seamen's market have been undertaken on Kalaw Street, historically the location of Manila's major manning agencies. This is where utility men assigned to scout for seafarers that their agencies needed go. The specific method of participant observation employed is 'hanging out' (Geertz, 1998; Rodgers, 2004; Woodward, 2008), which enabled 'intensive informal and interpersonal interactions' (Rodgers, 2004: 48) with utility men. In the initial stage of my participant observation, I was assisted by a utility man I interviewed in the early part of my fieldwork. As he was assigned to recruit seafarers at the seamen's market, many of the utility men there were his good friends. His presence and acting as my 'guide' helped overcome difficulties in engaging them. His introduction allowed me to go past suspicions about who I was and what I was doing. This hastened the process of earning their trust and enabled me to explain the purpose of my research. Over the course of my participant observation, our conversations dwelt on their family, lives and experiences, work history, hopes and anxieties, as well as the daily struggles they faced. Informed consent was obtained and all participants were assured of anonymity and confidentiality.

Fieldnotes and interview transcripts were coded and thematically analysed. The analysis of data was guided by analytic induction, which required the inference of general conclusions based on particular cases. Initial hypotheses were formulated, then refined through seeking out falsifying evidence from the data. Theoretical conclusions were then modified in light of this falsifying evidence (Bloor, 1978). This article focuses on how utility men and manning agencies used and rationalized utility manning, a theme critical to understanding the utility men-manning agency relationship.

\section{Utility manning as a technology of servitude}

The manning agency-utility men relationship involves the agencies delivering on the promise of employment at some future time, a fulfilment contingent on the utility men's proving themselves worthy of it. Aware of this, utility men try to win the favour and approval of their bosses by showing themselves to be exemplary, if not exceptional, utility men. Manning agencies use this period of utility manning to make them form the 'proper dispositions' of a seafarer. 


\section{The politics of standing}

Utility men working as office assistants were not allowed to sit down. Sitting down was a sign of inactivity, and hence of laziness. As such, it indicated a lack of discipline and commitment, as well as arrogance in so much as sitting down suggested 'one did not want to work'. The act of standing was both a sign of subjection to authority and their readiness to serve. It indicated their attentiveness to the needs of their superiors. Making utility men stand was thus a means of disciplining the utility men's bodies in order for them not only to take on an acceptable appearance (of being hard at work and therefore earning their placement on-board a ship) but also of putting them in their right place. By making them stand and stand at attention like guards ready to spring to action for service - manning agencies ensure that utility men inhabit the spaces of their servitude. Standing embodies their position and positioning as servants within the organization, as well as their submission to authority. It made them feel like fools (parang tanga) and become like a piece of furniture. Indeed, they were made to function as a device or tool to make others' lives easier.

\section{The politics of wasting time}

Some manning agencies 'waste' their utility men's time, showing no value to or consideration for the time and work they have already invested into the job. Roger ( 24 years old), who drove his manager and fellow utility men to the seamen's market, was dismissed when he was found dozing off in the vehicle. ${ }^{2}$ He begged for 'forgiveness', stopping short of kneeling, to no avail. It took him several months to find another agency to work for. Rafael (24), who had already worked as a utility man for three months and had in fact a schedule to board his ship, said that his service was extended for another six months for the crime of pressing all the floor numbers of their building's lift. His manager, who got on the lift just as Rafael got out, was furious because his flight up or down the building was inconvenienced by Rafael's action.

Utility men work very hard in order to impress their bosses and tread very carefully to avoid displeasing them. If they did, they ran the risk of being kicked around, that is, their servitude prolonged, or worse, kicked out. Their agencies play with their desperation, exercising power over their lives and futures. As one utility man said, they are treated like toys (laruan). Utility men's time being wasted demonstrates their insignificance and the power agencies exercise over them. Lucht (2011: 72) writes that 'having one's time wasted or negated is a central experience for the subalterns of the world'. As Bourdieu (2000: 228) noted, 'the art of ... making people wait, of delaying without destroying hope, of adjourning without totally disappointing, which would have the effect of killing the waiting itself, is an integral part of the exercise of power'. Manning agencies behave with impunity and utility men accept these 'punishments' with impotent rage. They cannot leave or just walk away because they would have to start all over again. As Gary (22), said: 'They make us feel very small, like we are nothing and worthless, that we are there because we are desperate for a job, and we would do anything for it.'

\section{The politics of silence}

A fleet manager in a big manning agency underscored the importance of commitment and dedication to undertake utility manning. As a fleet manager, he had several utility 
men under him. He asserted that utility manning was a test of character and good preparation for work on a ship. It was therefore a time when utility men must demonstrate or prove their ship worthiness. I posed to the manager the hypothetical case of a utility man quitting for financial reasons and not because he did not have the determination. He explained that the agency was doing the utility men a favour by accepting them and they should be grateful for it. In other words, manning agencies are benefactors whose paternalist benevolence saves utility men from wasting away in unemployment. He argued that utility men should be able to find ways to finance their utility manning and that poverty, for those determined and resourceful enough, should not stop them from realizing their goal. His statement insists upon the limits of the moral obligation the agency has for utility men, which is, at the proper time, it places them on a ship. Within the moral economy of this patron-client tie, the agency is not obligated to provide monetary assistance even when the difficulties happen during their utility manning because the agency's favour happens at the beginning and end: their accepting the utility men and their placing them on a ship. This is more than enough 'payment' for the services rendered by utility men so that what happens in between should be the responsibility of the utility man and his family. For the fleet manager, this does not constitute a shirking of their obligation nor an abandonment of utility men.

The fleet manager pointed out that at manning agencies, utility men learn to deal with different people, subdue their emotions and take whatever is thrown at them. He emphasized the importance of being able to control their emotion and temper, of being able to bite their tongue in order to stay out of trouble. The ship is a far crueller place than a manning agency and those who give up do not really possess the determination and resilience necessary for ship-work. Many interviewees shared their stories of bosses who justified abuse of authority as preparation for life on-board a ship. Their keeping quiet even if they were raging was good training as this will help them stay out of trouble.

He said that utility men should learn that hot-headedness was not going to take them far. A bad evaluation report from the ship's captain can ruin their career. Utility men should learn to deal with difficult people and situations in a very hierarchical 'total institution', where they are the lowest creature. Those joining a ship for the first time must know how to subordinate themselves to everyone else. It was costly to be assertive. As he said,

Would they risk losing their opportunity simply because in the heat of the moment, they let their pride get the better of them? Would that not be wasting all their hard work and sacrifices? Would that not put to waste their parents' sacrifices for them?

Utility men are reminded of their place and priorities. They needed a job and they had families to support. Would-be seafarers are being instructed to learn to get along with everyone, even with those who are making their lives miserable. This simply means that they bite their tongue, shut up and, as the fleet manager said, 'think of the bigger picture'. Manning agencies thus perform a pedagogical role, preparing utility men for subservience, an effective means of pleasing others and staying out of trouble. They are, in other words, engaged in practices of manufacturing docility. These agencies have a vested interest in making this happen: this helps to ensure the continued custom of shipowners who do not want to deal with 'troublesome' workers. 'Troublemakers' and 'assertive 
seafarers' who report abuses and irregularities will find difficulty in getting a new contract, if they are not told to find a new agency.

Utility manning becomes a mechanism through which agencies attempt to produce pliant and compliant workers by combining physical and verbal abuse: standing designed to inculcate not only bodily comportment but also the embodying of a servile position and mentality; wasting of time and indefinite waiting to foster an ideology of patience (Auyero, 2012); and finally, the inculcation of silence as virtue and strategy of keeping out of trouble and ensuring their employability.

\section{Utility manning as a technology of imagination}

Although utility men have come to see getting used to abuse as 'good preparation for life on a ship', thus indicating acceptance, if not internalization, of agency staff's rationalization of their treatment of utility men, they nevertheless saw utility manning as vitally important in changing their experience of waiting and their prospects in life. This section examines how utility men used utility manning to counteract waithood and the anxieties engendered by waiting and unemployment. Equally important, it demonstrates how these young men framed their servitude within their present life situation and the life trajectory they desire.

\section{Utility manning as active and purposeful waiting}

'Just lying in bed is exhausting.' This was how Greg (28) described how he passed the time. He had spent the past eight months applying to become a utility man with no luck. His experience of time as a heavy burden and as moving slowly demonstrates how the lack of work or meaningful activities to do deprived him of a vital way of organizing even his daily life. In contrast, Mark (24) said that by utility manning, 'the hours and days go quickly by. Unlike when you're not doing anything, you do not know how to spend the time. You feel time become heavier, move more slowly.'

Utility manning provided structure and content to the utility men's time. More than just making them busy, utility manning gave them a sense of agency. They were not simply waiting for something to happen. They were making something happen. Their utility manning made their waiting active and purposeful. This is evident in what the friends of Rafael said to him about the extension of his servitude for six more months. Andy (21) said, 'It was tough, what they did but if you think about it, it is still okay because you know that you'll still be able to go. Your service just got longer.' Bert (23) added: 'What's hard is to wait without knowing when you are going, without certainty. It's hard to just wait and wait.' Both Andy and Bert pointed to the assurance of a job that utility manning provided, which helped them fight off the feeling of wasting away and being stuck.

\section{Utility manning and the agency of imagination}

Becoming a utility man signalled a change in the prospects of a would-be seafarer. It was taken by the utility men as indicating that their departure will come and it was just a matter of working-waiting for it. Philip (29) said that utility manning 'enabled him to see himself 
finally getting close to his dream of giving himself and his family a much better life'. Martin (26) said that it made 'the prospect of boarding a ship both possible and real' and so trained his eyes on the prize: 'I don't dwell on the hardship. I think about the time when I am already earning and what I could do for my family.' Utility manning made realizing their goals achievable. This life-changing possibility is what they saw beyond their suffering. The promise of a future yet to come sustained them. Translating servitude as their means of remaining hopeful and hanging on to their life's goals depended on the work of imagination. In the Philippines where these young men and their families alone bear the responsibility of social reproduction, hope, imagination and resilience become powerful resources to soldier on despite the social, economic and structural odds ranged against them.

Purposeful waiting, hope and imagination became entwined. Hope strengthened their capacity to wait (Mar, 2005) and the exercise of defiant imagination depended on hope (Boden and Epstein, 2011). More than guaranteeing a job, utility manning enabled utility men to (fore)see a better life, which shaped their behaviour in the present. The future that they imagined for themselves and their families vitally shaped the choices they made and how they acted and behaved in the present (Flaherty, 2014). By using utility manning to navigate an uncertain future, utility men turned it into a 'technology of imagination' (Vigh, 2009).

\section{Utility manning as pathway to social adulthood}

Utility manning provided a means for young men to transition from unemployment to employment, and from being dependent to being depended upon. While utility manning, the young men relied on their parents, older siblings or other kin for financial support. When they obtain work on a ship, however, the possibility for performing a completely different role - being their family's financial provider - presents itself. As Joemari (23) said:

I want to help my family. My younger sibling is going to university soon but my family cannot afford it. He wants to do an IT degree but I told him to take up a TESDA [short vocational/ technical] degree instead. While I haven't gone on-board a ship, he'll have to make do with it. Once I am on-board, I will help him do the degree he likes. That's why I can't wait to get on a ship.

This possibility is bound up with international labour migration because as Anton (23) said, 'If you stayed and worked here, nothing is going to happen to you.' Staying in the Philippines was not an option. Even if he found a job in the Philippines, his salary would most likely be just sufficient for him to survive. On that salary, he cannot help his natal family and could not even think of having his own one day:

You won't be able to help your family. You won't think of having your own family because you won't be able to feed them. You won't be able to support them. Where will you get the money to send your children to school? I'd probably not be able to even afford to buy infant formula and diapers.

Utility manning offered utility men not only a pathway to international contract labour migration in the form of seafaring but also a means of fulfilling family obligations. All 
of the utility men said that anyone taking a maritime course aspires to work in international seafaring. Nobody ever aimed to work in the domestic sector where the pay is very low. As one said, 'It's nothing compared to what one makes internationally. You become a seaman because you want to earn in dollars.' When talking about pay, research participants always linked their aspiration for a better life to their obligations and responsibilities to their family: inter alia, financial provision for their family, the education of siblings, health care for elderly parents and much-needed house building or repairs.

\section{Discussion and conclusion}

While there is coherence between manning agencies and utility men around training and preparation for life on-board a ship, how utility men interpret their servitude as job and life strategy points to a radically different framing of utility manning. For them, it is a vitally 'path-breaking' activity to undertake. Hence, utility men felt no shame in doing it despite the abuse and humiliation attached to the job. Seafarers who also served as utility men and who have become captains, chief officers, chief engineers claimed that the bad treatment was a necessary evil to toughen up utility men. Toughening up, however, did not mean here being prepared to stand up for their rights or being assertive. Rather it meant utility men being able to put up with everyone else in the ship trying to exercise authority over them.

Manning agencies' use of utility manning to train utility men into docility and develop forbearance intersects with the construction and representation within the Philippines and globally of a specific subject of international labour migration - the docile seafarer. Chin (2008) has noted how South-East Asian, specifically Filipino and Indonesian, seafarers in the cruise line are preferred to other nationalities by employers allegedly because of their service culture. The ascription of servility to South-East Asian men feminizes them (Chin, 2008; Fajardo, 2011; McKay, 2007). Filipino seafarers have had to labour against perceptions of being physically weak, effeminate and homosexual (Ostreng, 2001), having an exaggerated respect for authority (Knudsen, 2004) and lacking in initiative (Ruggunan, 2005). McKay (2007: 624) has pointed out that the efforts of the Philippine state and manning agencies in the 1980s and 1990s to protect and further promote Filipino seafarers' niche in lower-level positions in international seafaring relied upon "endowing the "natural" Filipino seafarers with the "innate" qualities of pliability. [...] Thus Filipino seafarers not only remain in subordinate positions, but there is a growing emphasis on their "feminine" and willingly-subservient character.' Utility manning involves physical activities such as morning exercises just before start of work and jogging or running on weekends intended not only to help develop healthy and strong bodies but also a character capable of enduring hardship and being pushed beyond their limits. These physical activities aim to develop utility men who embody discipline and character that are inextricably bound up with obedience and subservience.

In contrast, the utility men derive from utility manning temporal agency and the agency of imagination. Through utility manning, they change the texture of their waiting. They do not suffer from the same boredom and empty time that non-utility men had to constantly deal with. Utility manning is also generative of temporal agency in that it enabled them to shape their future. Manning agencies at times negated their temporal agency by wasting their time, that is, prolonging their servitude for the flimsiest reasons. Nevertheless, utility men derived from their servitude 'an extended temporal horizon' 
(Wacquant, 2008: 217). Utility manning counters the condition of being stuck hence enabling the utility men to see themselves as adult men having their own families in due time and performing their obligations to their parents, siblings and other kin. The braiding of their utility manning with the future fulfilment of their performance of family and intergenerational responsibilities, which locates their masculine and adult identities within family, kin and wider social relations, also accounts for why the utility men seek out, consent to and endure their exploitation. Utility manning provides these young men with the means of assuming the most important role for adult Filipino men, breadwinning that enables them to perform family and kin obligations (Alipio, 2013; McKay, 2011). The young men thus turn servitude into their means of becoming adult men.

Utility manning is an informally negotiated link to international seafaring labour. Although their use of utility men as free labour is widely known, manning agencies have been left unregulated such that they have variable practices. For example, some provide utility men with a transportation allowance but most others do not. Better regulation by the government of crewing agencies as far as utility men are concerned is thus necessary to improve the situation of utility men. First, manning agencies could cap the length of service to a maximum of six months. Second, they could provide them a minimum daily allowance of 150 pesos (US\$3). Finally, in recent years, shipping associations, shipowners and their manning agencies have embarked on a programme of training Filipino seafarers to become senior officers in response to the global shortage of qualified officer seafarers. A number of interviewees pointed out that the way utility men are socialized into servility runs counter to this new direction in which Filipino seafarers now have more opportunities to take on operational and management-level positions where they need to exercise leadership and authority. In order to corner a big share of the seafaring labour market, the Philippine state's and manning agencies' promotion in the past of a subordinate and cautious masculinity which they, however, linked to a 'heroic' masculinity (seafarers as new heroes of the nation) 'to regulate the reactions of Filipino seafarers to harsh work-place conditions' (McKay, 2007: 630) is no longer appropriate. The state and manning agencies should take the opportunity opened up by the demand for more Filipino seafarer officers to change the way seafarers are trained and socialized. This necessarily includes changing the way utility men are treated in/by manning agencies.

\section{Acknowledgements}

I thank the anonymous reviewers for their comments that helped improve this article and Jason Hart and Jojo Nem Singh for feedback on drafts.

\section{Funding}

The article derives from work undertaken for the research project 'Working for Work', funded by the Deutsche Forschungsgemeinschaft (DFG/German Research Foundation) Grant GA 2241/1-1.

\section{Notes}

1. In the Philippines, the youth category refers to all those aged 15-30 years old (Republic Act 8044 - Youth in Nation-Building Act). For purposes of international comparison, the Philippine Department of Labour and Employment disaggregates data for the 15-24 and 25-30 age 
ranges. Youth unemployment figures presented here pertain only to the former age range. The empirical data and analysis presented here come from participants who have finished at least three years of maritime education, meaning they are at least 19 or 20 years old.

2. All names used are pseudonyms. Quotations from conversations and interviews have been translated into English.

\section{References}

Alderton T and Winchester N (2002) Globalisation and de-regulation in the maritime industry. Marine Policy 26(1): 35-43.

Alipio C (2013) Young men in the Philippines: mapping the costs and debts of work, marriage, and family life. Annals of the American Academy of Political and Social Science 646(1): 214-232.

Auyero J (2012) Patients of the State: The Politics of Waiting in Argentina. Durham, NC: Duke University Press.

Beynon J (2002) Masculinities and Culture. Buckingham: Open University Press.

Bloor M (1978) On the analysis of observational data: a discussion of the worth and uses of inductive techniques and respondent validation. Sociology 12(3): 545-552.

Bloor M (2011) An essay on 'health capital' and the Faustian bargains struck by workers in the globalised shipping industry. Sociology of Health \& Illness 33(7): 973-986.

Bloor M (2013) The rime of the globalised mariner: in six parts (with bonus tracks from a chorus of Greek shippers). Sociology 47(1): 30-50.

Bloor M and Sampson H (2009) Regulatory enforcement of labour standards in an outsourcing globalised industry: the case of the shipping industry. Work, Employment and Society 23(4): 711-726.

Boden R and Epstein D (2011) A flat earth society? Imagining academic freedom. Sociological Review 59(3): 476-495.

Bolton S and Laaser K (2013) Work, employment and society through the lens of moral economy. Work, Employment and Society 27(3): 508-525.

Bolton S, Houlihan M and Laaser K (2012) Contingent work and its contradictions: towards a moral economy framework. Journal of Business Ethics 111(1): 121-132.

Bourdieu P (2000) Pascalian Meditations. Palo Alto, CA: Stanford University Press.

Chapman P (1992) Trouble on Board: The Plight of International Seafarers. Ithaca, NY: Cornell University Press.

Chin C (2008) Labour flexibilization at sea. International Feminist Journal of Politics 10(1): 1-18.

Couper A, Walsh C, Stanberry B and Boerne G (1999) Voyages of Abuse: Seafarers, Human Rights and International Shipping. London: Pluto Press.

Danish Trade Council for International Development and Cooperation (DTCIDC) (2016) Labour Market Profile 2016: The Philippines. Copenhagen: LO/FTF Council.

Department of Labor and Employment (DOLE) (2017) Summary of current regional daily minimum wage rates: non-agriculture, agriculture. Available at: http://www.nwpc.dole.gov.ph/ pages/statistics/stat_current_regional.html (accessed 29 June 2017).

Elliott J (2005) Using Narrative in Social Research: Qualitative and Quantitative Approaches. London: SAGE.

Fajardo KB (2011) Filipino Crosscurrents: Oceanographies of Seafaring, Masculinities and Globalisation. Minneapolis, MN: University of Minnesotta Press.

Fernandez-Kelly P (2005) Reforming gender: the effects of economic change on masculinity and femininity in Mexico and the U.S. Women's Studies Review Fall: 69-101.

Finn B and Oldfield S (2015) Straining: young men working through waithood in Freetown, Sierra Leone. Africa Spectrum 50(3): 29-48. 
Flaherty M (2014) The Textures of Time: Agency and Temporal Experience. Philadelphia, PA: Temple University Press.

Foucault M (1997) Technologies of the self. In: Rabinow P (ed.) Ethics: Subjectivity and Truth. New York: New Press, 223-252.

Geertz C (1998) Deep hanging out. New York Review of Books 45(16): 69-72.

Hansen KT (2005) Getting stuck in the compound: some odds against social adulthood in Lusaka. Africa Today 51(4): 2-17.

Honwana A (2012) The Time of Youth: Work, Social Change and Politics in Africa. Sterling, VA: Kumarian Press.

IBON Foundation (2016) Change underway? Available at: http://ibon.org/file/2015/11/2016Yearend-Birdtalk_Change-Underway.pdf (accessed 20 June 2017).

International Transport Workers Federation (ITF) (2014) ITF uniform 'TCC' collective agreement for crews on flag of convenience ships. Available at: http://www.itfseafarers.org/files/seealsodocs/33560/UNIFORM\%20TCC\%202015\%2D2017\%20FINAL.pdf (accessed 30 March 2017).

Jauregui B (2014) Provisional agency in India: jugaad and legitimation of corruption. American Ethnologist 41(1): 76-91.

Jeffrey C (2008) Generation nowhere: rethinking youth through the lens of unemployed young men. Progress in Human Geography 32(6): 739-758.

Jeffrey C (2010) Timepass: Youth, Class, and the Politics of Waiting in India. Palo Alto, CA: Stanford University Press.

Kerkvliet B (2013) Everyday Politics in the Philippines: Class and Status Relations in a Central Luzon Village. Quezon City, Philippines: Ateneo de Manila University Press.

Knudsen F (2004) If you are a good leader, I am a good follower: working and leisure relations between Danes and Filipinos on board Danish vessels. Available at: http://static.sdu.dk/mediafiles/Files/Om_SDU/Institutter/Ist/MaritimSundhed/Rapporter/report92004.pdf (accessed 6 July 2017).

Kohlrausch B (2012) Youth Unemployment in Germany: Skill Biased Patterns of Labour Market Integration. Bonn: Friedrich Ebert Stiftung.

Lewis D (2008) Using life histories in social policy research. International Social Policy 37(4): $559-578$.

Lucht H (2011) Darkness before Daybreak: African Migrants Living on the Margins in Southern Italy Today. Berkeley, CA: University of California Press.

McDowell L (2003) Redundant Masculinities: Employment Change and White Working Class Youth. Oxford: Blackwell.

McKay S (2007) Filipino sea men: constructing masculinities in an ethnic labour niche. Journal of Ethnic and Migration Studies 33(4): 617-633.

McKay S (2011) Re-Masculinising the Hero: Filipino Migrant Men and Gender Privilege. Asia Research Institute Working Paper Series No. 172. Singapore: ARI.

Mains D (2013) Hope Is Cut: Youth, Unemployment and the Future in Urban Ethiopia. Philadelphia, PA: Temple University Press.

Mar P (2005) Unsettling potentialities: topographies of hope in transnational migration. Journal of Intercultural Studies 26(4): 361-378.

Masquelier A (2005) The scorpion's sting: youth, marriage and the struggle for maturity in Niger. Journal of the Royal Anthropological Institute 11(1): 59-83.

Ostreng D (2001) Does togetherness make friends? Stereotypes and intergroup contact on multiethnic-crewed ships. Available at: http://www-bib.hive.no/tekster/hveskrift/notat/2001-02/ index.html (accessed 20 June 2017).

Parrenas RS (2005) Children of Global Migration: Transnational Families and Gendered Woes. Stanford, CA: Stanford University Press. 
Philippine Statistics Authority (2017) 2016 Annual LFS estimates tables. Table 1: Number and percentage distribution of population 15 years old and over by employment status, by sex and age group 2016. Available at: https://psa.gov.ph/content/2016-annual-lfs-estimates-tables (accessed 6 July 2017).

Pingol A (2001) Remaking Masculinities: Identity, Power, and Gender Dynamics in Families with Migrant Wives and Househusbands. Quezon City, Philippines: University of the Philippines Centre for Women's Studies.

Roberts C (2017) The Inbetweeners: The New Role of Internships in the Graduate Labour Market. London: Institute for Public Policy Research. Available at: http://www.ippr.org/publications/ the-inbetweeners (accessed 19 June 2017).

Rodgers G (2004) 'Hanging out' with forced migrants: methodological and ethical challenges. Forced Migration Review 21: 48-49.

Rose N (1999) Powers of Freedom: Reframing Political Thought. Cambridge: Cambridge University Press.

Rudnyckyj D (2004) Technologies of servitude: governmentality and Indonesian transnational labour migration. Anthropological Quarterly 77(3): 407-434.

Ruggunan S (2005) Rough seas for South African seafarers in the merchant navy: the global is the local. Transformation: Critical Perspectives on South Africa 66: 56-80.

Scott J (1972) Patron-client politics and political change in Southeast Asia. American Political Science Review 66(1): 91-113.

Scott J (1976) The Moral Economy of the Peasant: Rebellion and Subsistence in Southeast Asia. New Haven, CT: Yale University Press.

Sommers M (2012) Stuck: Rwandan Youth and the Struggle for Adulthood. Athens, GA: University of Georgia Press.

Thieme A (2017) The hustle economy: informality, uncertainty and the geographies of getting by. Progress in Human Geography. Epub ahead of print 2 February. DOI: $10.1177 / 0309132517690039$.

Thompson EP (1971) The moral economy of the English crowd in the eighteenth century. Past and Present 50(1): 76-136.

Vigh H (2009) Wayward migration: on imagined futures and technological voids. Ethnos 74(1): 91-109.

Wacquant L (2008) Urban Outcasts: A Comparative Sociology of Advanced Marginality. Malden, MA: Polity Press.

Walters D and Bailey N (2013) Lives in Peril: Profit or Safety in the Global Maritime Industry? Basingstoke: Palgrave Macmillan.

Woodward K (2008) Hanging out and hanging about: insider/outsider research in the sport of boxing. Ethnography 9(4): 536-560.

Roderick G Galam is a research associate at the Institute of Social and Cultural Anthropology, Free University of Berlin and was a visiting research fellow at the International Migration Institute, Oxford University in 2017. His current project, Working for Work, is funded by the German Research Foundation. His research interests include temporality, youth unemployment, educationto-work transition, social adulthood and masculinity. He is the author of the book Women Who Stay: Seafaring and Subjectification in an Ilocos Town (2018).

Date submitted October 2016

Date accepted January 2018 